\title{
The Use of YouTube Video toward Students' Listening Ability
}

\author{
Dian Shafwati ${ }^{1}$, Lilis Sholihah ${ }^{2}$, Gita Hilmi Prakoso ${ }^{3}$, Fajar Riyantika ${ }^{4}$ \\ \{dianshafwati@fkip.unila.ac.id ${ }^{1}$, lilissholihah1986@gmail.com² ${ }^{2}$ gitahilmi@gmail.com³ \\ fajarriyan87@gmail.com ${ }^{4}$ \} \\ Universitas Lampung, Bandar Lampung, Indonesia ${ }^{1,2,3,4}$
}

\begin{abstract}
This study was focused on identifying the influence of YouTube videos, as a listening learning media. It is believed that the audio visual mode may improve students' listening ability, and make listening more interesting. In this study, pre-experimental quantitative, with one group pre-test post-test, was applied. This research design was intended to analyze students' listening ability both at the initial, and final part. The subjects of this study were 23 undergraduate students of English Department, University of Lampung, taken from pre intermediate listening class. After the calculation of Paired sample t-test, it was found that the result of the two tailed significance was 0.000 . Therefore, it can be concluded that there is significant influence of using YouTube videos toward students' listening comprehension. Regarding students' perception toward the use of YouTube videos, a survey in the form of a questionnaire was also distributed to all 23 students. The results showed that all participants assumed that using YouTube videos made listening class more encouraging.
\end{abstract}

Keywords: Listening, YouTube, Video

\section{Introduction}

Listening is one of the hardest skills in English especially for students with low competence [1]. Listening will become more difficult if the conversation recording is made by the native speaker which has different accent and speed. Listening is also considered as boring subject since students only listen to the conversation recording again and again. Furthermore, most of conversations used in listening contain topic or issue which are not new and not suitable with students in Indonesia.

Lately, invention of technology makes listening able to be taught not only through audio media but also through audio-visual media like video. In fact, [2] in his research stated that the process of classroom activities will be more efficient if visual media are involved as $11 \%$ from the given material occurs through sense of hearing, and $83 \%$ through the seeing devices of human beings. From that research, audio-visual media like video is very suitable in teaching listening to make the teaching and learning more effective and easy.

Through video, especially YouTube video as the largest video provider on the internet, it can increase students' listening understanding, and it also can develop a variety of the newest topic or new issue [3]. Beside that, video also allows students to recognize mimic and 
gesture/movement from every speaker in conversation [4]. Several studies have been done related to students' attitude toward the use of YouTube video in teaching listening.[5] and [6] investigated students' reactions on the application of YouTube audio-visual mode. It showed that the students have a positive attitude toward the utilization of YouTube in the classroom. The study found that not only students' eagerness improved but also their cooperation to be involved in class activities. Furthermore, [7] revealed that students have assumed that any listening task conducted by involving YouTube made the learning itself encouraging. In line with [8] research which discovered that students were encouraged in learning English listening after YouTube videos were utilized in the listening classroom.

From the previous research above, it shows that teaching listening by using YouTube makes learning become more interesting and students become motivated. However, it is rare to find the study which focuses on students' listening comprehension after being taught by using YouTube videos. Therefore, this research will find out: 1. How is the influence of YouTube video toward students' listening comprehension?; and 2. How is the students' perception toward teaching listening by using YouTube video?. This research is carried out for the advancement of students' listening teaching and learning in the latest teaching media. In addition, it is also expected to improve students' listening comprehension and make teaching and learning listening more enjoyable.

\section{Method}

A quantitative pre-experiment with one group pre-test and post-test design was employed in this study. This design was chosen as this study involved only one class, where listening ability of the students assessed at the beginning and at the end. The findings included the results of listening pre-test and post-test, and responses to a set of questionnaire of 23 students.

The procedure of data collection was started by administrating pre-test to the students of Pre-intermediate Listening Class. After that, video lesson by optimizing YouTube as main source was applied. Finally, to assess the listening skill after the students were taught using YouTube videos, post-test was given. The results of pre-test and post-test were compared to see the significance of YouTube videos in listening class.

$\mathrm{T} 1 \times \mathrm{T} 2$

T1 referred to pre-test that was administered before the video class treatment, $\mathrm{X}$ referred to the treatment application conducted by the researcher using YouTube videos to teach, in order to improve listening ability [9]. T2 referred to post-test to see the result after the treatment.

\subsection{Participants}

Undergraduate students of Pre-intermediate Listening Class in English Department Unila were participated in this research. 23 students were taken to participate in this study. This study involved cluster sampling to choose the participants. According to [10] cluster sampling involves grouping process of a population. This sampling technique also focuses more in involving the group as a whole unity rather than identifying each individual in the chosen 
group. This technique is very relevant to the setting of this study, since the participants were a group of students that had been clustered into several groups in a system organized by the institution.

\subsection{Instruments}

1. Listening Test

A listening test was administered to obtain the data from the students ,. There were two tests, the pre-test and the post-test that the results were compared to see the significance of the treatment.

2. Questionnaire

The questionnaire consisted of 9 items that are intended to identify students' perception regarding the application of YouTube videos in listening class. The questionnaire was a likertscaled-design with the scales of 1 (strongly disagree) to 5(strongly agree).

\subsection{Data Analysis}

The data of the tests results were analyzed using SPSS by firstly inputting the scores to Excel spreadsheet. The overall scores of both pre-test and post-test were calculated to see the significance of the use of YouTube videos. For the questionnaire responses, the data was given in the form of chart and percentage of different responses of each item.

\section{Research Findings and Discussion}

In this research, the researchers administered a pre-test before the treatment and a post-test after the treatment. The aim was to find out whether there was any significant improvement of students' listening comprehension after the implementation of YouTube videos. Paired Sample T-Test in SPSS 20 version was used in analyzing the data of the tests. Based on the result of the pre-test, it can be clearly seen that the students' score ranged between 60-86. The mean score of the pre-test was 76.65 , with the lowest score was 60 and the highest one was 86 . On the other hand, the range of students' score of post-test lies between 76 - 96. It shows that the minimum score of post-test is 76 and the maximum one is 96 , while the average score is 82,04 . Therefore, it can be justified that students' score in listening comprehension improved after the implementation of treatment.

Moreover, the normality test was used to make sure whether the data of the test were distributed normally. The researchers utilized One Sample Kolmogorov-Smirnov Test with SPSS 20 for Windows. The description of the normality distribution result explained in the table below:

Table 1. Normality Test

\begin{tabular}{|c|}
\hline Kolmogorov-Smirnov Test (One Sample) \\
\hline Unstandard \\
zed \\
Residual \\
\hline
\end{tabular}




\begin{tabular}{|c|c|c|}
\hline \multicolumn{2}{|l|}{$\mathrm{N}$} & 23 \\
\hline \multirow{2}{*}{$\begin{array}{l}\text { Normal } \\
\text { Parameters }\end{array}$} & Mean & 0E-7 \\
\hline & $\begin{array}{l}\text { Std. } \\
\text { Deviation }\end{array}$ & 4,6579358 \\
\hline \multirow{3}{*}{$\begin{array}{l}\text { Most } \\
\text { Differences }\end{array}$} & Absolute &, 159 \\
\hline & Positive & , 159 \\
\hline & Negative &,- 108 \\
\hline \multicolumn{2}{|c|}{ Kolmogorov-Smirnov Z } & ,764 \\
\hline \multicolumn{2}{|c|}{ Asymp. Sig. (2-tailed) } & ,604 \\
\hline
\end{tabular}

According to the table above, the data were normally distributed since the significance value ( 2 tailed) is higher than $0,05(0,604)$. After the data had been distributed normally, hypothesis testing was conducted. It was used to prove whether the hypothesis proposed by the researcher was accepted or not. To examine the hypothesis, the researcher used statistical computation Paired Sample T-Test SPSS 20 version for Windows.

Table 2. Paired Sample Statistics

\begin{tabular}{|rcccc|}
\hline Paired Samples Statistics & & \\
\hline & Mean & $\mathrm{N}$ & $\begin{array}{c}\text { Std. } \\
\text { Deviation }\end{array}$ & $\begin{array}{c}\text { Std. Error } \\
\text { Mean }\end{array}$ \\
\hline $\begin{array}{r}\text { PRE } \\
\text { TEST }\end{array}$ & 76,6522 & 23 & 6,35044 & 1,32416 \\
Pair 1 $\begin{array}{r}\text { POST } \\
\text { TEST }\end{array}$ & 82,0435 & 23 & 5,40604 & 1,12724 \\
\hline
\end{tabular}

Table above presents the mean scores of students' listening comprehension in both pretest and post-test. The mean score in pre-test is 76.65 while the mean score in the post-test is 82.04. It means that the mean score gained 5.39. To see whether the influence was significant or not, the result of paired sample t-test is explained in the following table:

Table 3. Paired Sample T-Test

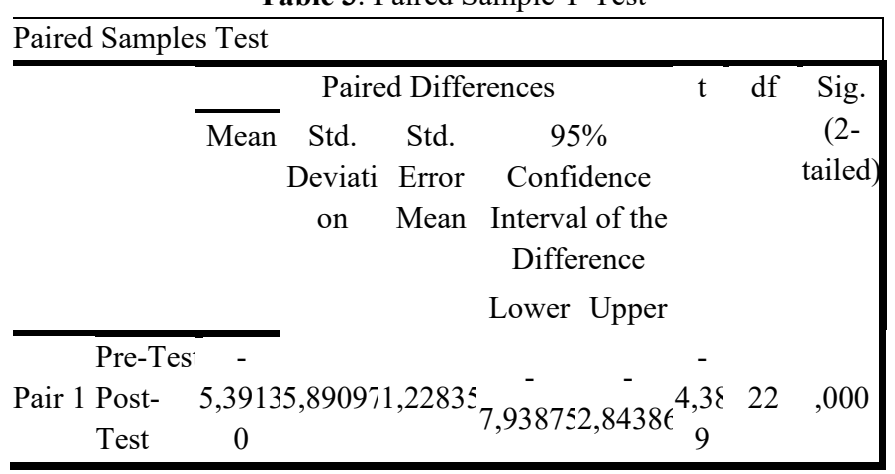


The table shows that the significance value ( 2 tailed) is 0.000 . It indicates that the influence is significant since 0.000 is less than $0.05(0.00<0.05)$. It means that $\mathrm{H}_{0}$ is rejected, while $H_{1}$ is accepted that there is significant influence of using YouTube videos on students' listening comprehension. Therefore, it can be concluded that there is significant influence of using YouTube videos toward students' listening comprehension.

The finding of this study is in line with another previous study from [11] who investigates the effectiveness of using YouTube toward Students' listening comprehension skills. The design of the research is quasi experimental design with experiment and control group design. The result showed that using YouTube had indeed enhanced Saudi EFL students' listening comprehension performance. After watching videos, the experiment group which is given the treatment by using YouTube video performed better than the control group in the post test which indicated their improvement in listening comprehension.

Moreover, this study has positive correlation with another previous study from [12] with the title Improving the Listening Skill of The Eighth Graders of MTs Negeri Jember II Using YouTube Internet Site. The method of her research is collaborative classroom action research. After conducting the study, the researcher found that the use of YouTube Internet sites can improve the students' listening skill. The improvement can be known by the increased score of the students' listening comprehension cycle 1 and cycle 2 The average score in Cycle 1was 69,4 while the average score in the end of implementation (cycle 2) of this study was 78.1.

Concerning students' perception of listening class with YouTube videos, all of the students were asked to fill in the form of a questionnaire after the lessons were completed. The result showed that all students believed that using YouTube videos made listening class more interesting (Figure 1).

\section{Video from youtube makes listening practice interesting}

23 responses

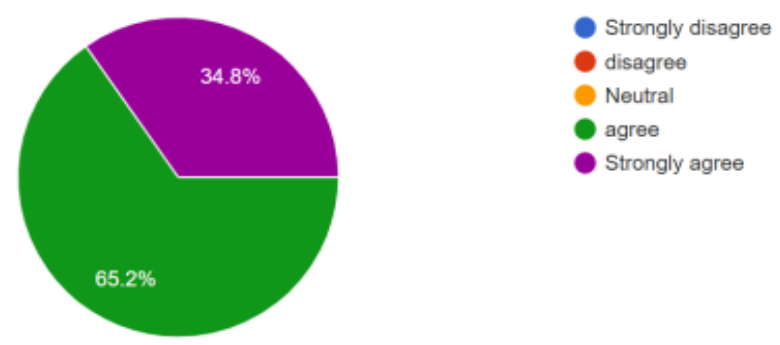

Fig 1. Student's perception 1

Based on the chart above, the questionnaire shows that $65,2 \%$ agree and $34,8 \%$ strongly agree that Video from YouTube makes listening practice interesting. It means that all students agree that listening to the classroom is more interesting after being taught by Video from YouTube. This finding is in line with [13] who stated that YouTube videos not only generate 
interest in the lesson but also explore students' imagination and make learning fun and meaningful.

Furthermore, $91 \%$ of the samples assumed that YouTube videos helped them to understand the lesson better when listening to English conversation. It means that the meaning of the recording/conversation is easier to be comprehended after being taught by Video from YouTube. This finding is in line with [14] who stated that through videos, students were supported by conceptualization and visualization, provided them memory cues and connections, and clarified understanding. These students listening conversation understanding are helped by the gesture and mimic of the speaker contained in the video from YouTube.

Next, $87 \%$ of respondents thought that YouTube videos gave contextual examples that could relate to real life situations. This occurred because the use of YouTube video provide students with variations of conversation that relate to real life context such as phone call conversation, book hotel conversation, shopping conversation, etc. This finding is in line with [15] who stated that YouTube videos can show students the real-world examples of material and theory covered in class.

On the other hand, almost all students, $60 \%$ responses, say that Video from YouTube does not help students to get a better understanding of associated cultural aspects. This happened because the video from YouTube that the researcher gave to students contained more global and universal contents. So, the video from YouTube that contains cultural aspects is not too purposely given. Further, $45 \%$ responses did not agree that Video from YouTube helps them in understanding vocabulary and idiomatic expression in the recording/conversation. This might be because there is no further explanation and discussion by the researcher about the idiomatic expression contained in the YouTube video.

\section{Conclusion and Suggestion}

\subsection{Conclusion}

Based on the result of the test, there is a distinguishable impact of using YouTube videos toward students' listening ability. After analyzing the result of the tests and the questionnaire, the researchers find that the result of the listening ability of the students based on the test shows that most of the first year students of University of Lampung have significant improvement in the score of post test than pre test. It is shown that the mean score in pre-test is 76.65 while the mean score in the post-test is 82.04. It means that the mean score gained 5.39.

Furthermore, the result of the table shows that the two tailed significance is 0.000 . It indicates that the influence is significant since 0.000 is less than $0.05(0.00<0.05)$. It means that $\mathrm{H}_{0}$ is rejected, while $\mathrm{H}_{1}$ is accepted that there is significant influence of the use of YouTube videos on students' listening comprehension.

Taking closer look at the questionnaire responses, based on the result of students' assumptions of listening class with YouTube audio-visual mode, all students agree that YouTube videos provide more excitement and encouragement in listening class. Further, $91 \%$ of the samples agreed that YouTube videos aided them to understand better when listening to English 
conversation recording. Next, $87 \%$ of respondents believed that YouTube videos gave real-life examples that could relate to actual situations on a daily basis. On the other hand, $60 \%$ of responses said that Video from YouTube does not help students to get a better understanding of associated cultural aspects.

\subsection{Suggestions}

Considering the positive result of YouTube videos in listening class, the researcher suggests that English lecturer/teacher should apply the use of YouTube videos in their listening class or other classes such as speaking class. It is also suggested that to find out the problem happened in the classroom when using YouTube video in order to make the learning and teaching process run smoothly. For the further researcher, it is also suggested that to conduct a research of the use of YouTube video in other classes like speaking class. It is suggested to have further research concerning the students' perception toward the use of Youtube video in other classes such as speaking class.

\section{References}

[1] Cahyono, Setyo P. "The implementation of genre based approach to teaching narrative listening”. (ASSEHR).2017; 66, 284-289

[2] Rusman, et. all. Pembelajaran berbasis teknologi informasi dan komunikasi: mengembangkan profesionalitas guru. Jakarta. Rajawali Press; 2012.

[3] Karkera, S., \& Chamundeshawari. C. YouTube: a teaching tool to improve listening skills. International Journal of Creative Research Thoughts (IJCRT).2018; 6, (2), 13111316

[4] Harmer, J. How to teach English. Edinburgh: Pearson Education Limited; 2007.

[5] Damronglaohapan, S., \& Stevenson, E. Enhancing listening skills through movie clips on YouTube. The European Conference on Technology in the Classroom, Official Conference Proceedings. 2013.

[6] More, N. B. Student attitudes towards the integration of YouTube in online, Hybrid, and Web-Assisted courses: an examination of the impact of course, modality on perception. MERLOT Journal of Online Learning and Teaching. 2015; 11(1), 55-73.

[7] Kelsen, B. Teaching EFL to the i generation: asurvey of using YouTube as supplementary material with college EFL students in Taiwan. CALL-EJ Online. 2009.10(2), 1-18.

[8] Silviyanti, T.M. Looking into EFL students' perceptions in listening by using English movie videos on YouTube. Studies in English Language and Education. 2014; 1(1), 45 63.

[9] Setiyadi, B. Metode Penelitian untuk Pengajaran Bahasa Asing: Pendekatan Kuantitatif dan Kualitatif Edisi 2. Yogyakarta: Graha Ilmu. 2018.

[10] Kothari, C.R. Research methodology: Methods and techniques. New Age International. 2004.

[11] Alqahtani. The effectiveness of using YouTube on enhancing students' listening comprehension skills. Riyadh: Department of English Language and Translation. 2014. 
[12] Marti. Improving the Listening Skill of The Eighth Graders of MTs Negeri Jember II Using YouTube Internet Site. Thesis, Graduate Program in English Language Education, State Universtiy of Malang. 2011.

[13] Berk, R. A. Multimedia teaching with video clips: TV, movies, YouTube, and mtvU in the college classroom. International Journal of Teaching and Learning.2001; 5(1), 1-21.

[14] Eick, C. J., \& King, D. T., Jr. Non-science majors' perceptions on the use of YouTube video to sup-port learning in an integrated science lecture. Journal of College Science Teaching. 2011;42(1), 26-30.

[15] Duffy, P. Engaging the YouTube google-eyed generation: Strategies for using Web 2.0 in teaching and learning. The Electronic Journal of e-Learning.2008; 6(2), 119-130. 